\title{
THE JUSTICE IN CREDIT AGREEMENTS WITH CLAUSULA STANDARD
}

\author{
Lathifah Hanim \\ Sultan Agung Islamic University \\ lathifah.hanim@yahoo.co.id
}

\begin{abstract}
Standard agreements have long been used in various contracts, the use of standard agreements is closely related to advances in the economy that require efficiency in spending costs, time and energy. A standard agreement is an agreement whose terms are standardized or determined by one party only, while the other party can only agree to it. The research objective is to determine and analyze the fairness of the credit agreement in the presence of standard clausulas. The research method uses juridical empirical. The results of the research are Contract justice can be seen in an agreement when both parties reach an agreement to bind themselves together without any pressure from other parties, in this case the contract is carried out voluntarily. Negotiations carried out in an agreement can also avoid one-sided contracts, and this is one of the first steps in creating a fair contract.
\end{abstract}

Keywords: Credit Agreement; Fairness; Standard Clausula.

\section{A. INTRODUCTION}

Basically, the agreement originates from the difference or inequality of interests between the parties. Generally, the formulation of a contractual relationship begins with a negotiation process between the parties. Through negotiation, the parties try to create forms of agreement to mutually reconcile what they want (interests) through a bargaining process. ${ }^{1}$

A credit agreement is an agreement made between a bank and a third party, in this case, the customer. A credit agreement can actually be compared to a debt agreement. The difference is that the term credit agreement is generally used by the bank as a creditor, while the loanreceivable agreement is generally used by the public and is not related to the bank.

The role of society in using credit facilities is as consumers or customers who are entitled to receive credit facilities from the bank. In this case the position of the bank and its customers are equal in the debt and credit agreement, but from an economic and social perspective, the position of the bank is higher than that of the customer because the bank has facilities that are used by its customers. ${ }^{2}$

1 Lathifah Hanim, MS.Noorman, Penyelesaian Perjanjian Kredit Bank Sebagai Akibatforce Majeure Karena Gempa Di Yogyakarta, Jurnal Pembaharuan Hukum, Volume III No. 2 Mei Agustus 2016, page.161-171

2 Gatot Supramono, Perbankan dan Masalah Kredit, Rineka Cipta, Jakarta, 2009, page.3 
The agreement is basically made based on freedom of contract. Everyone is given the freedom to contract to make agreements both in terms of form and content. Freedom of contract can be concluded from the provisions of Article 1338 paragraph (1) of the Civil Code "that the agreement made legally applies as law for those who make it". The principle of freedom of contract is a principle that gives the parties the freedom to make or not enter into an agreement, enter into an agreement with anyone, determine the contents of the agreement, its implementation and requirements and determine the form of the agreement, namely written or oral. $^{3}$

Article 1338 paragraph (1) of the Civil Code states that "all agreements made legally are valid as laws for those who make them. In this article, the principle of consensualism is found in the word ". Agreement made legally ..., which refers to Article 1320 of the Civil Code, especially in paragraph (1), namely they agreed to bind themselves.

Along with the development of various information technology-based transactions, standard agreements have entered a new form, namely in the form of electronic contracts. According to Act No.11 of 2008 concerning Electronic Information and Transactions, an electronic contract is an agreement between the parties made using an electronic system.

Some of the most commonly used electronic contracts include the clickwrap contract and the browsewrap contract. Provisions in electronic contracts are closely related to standard agreements. However, electronic system administrators are required to provide features that at least provide an opportunity for users to read the agreement before making transactions or choose to continue or stop carrying out subsequent activities.

Standardized in this agreement was not the agreement form, but the clausulas. However, the inclusion of the standard clausula has been regulated as in Article 18 of Act No. 8 of 1999 concerning Consumer Protection. The standard clausula becomes inappropriate when the position of the parties becomes unbalanced because basically, an agreement is valid if it adheres to the principle of consensualism agreed upon by both parties and binds both parties making the agreement as law. Thus, violation of the principle of consensualism may result in the agreement between the two parties being invalid, therefore, standard clausulas containing exonation clausulas are prohibited by law. The principle of consensualism is related to the birth of an agreement. Consensualism means that the agreement occurs because of the agreement or free will of the parties making the agreement regarding the content or subject of the agreement.

Lending from banks to debtor customers is based on a credit agreement, the credit agreement contains an agreement on the rights and obligations of each party between the bank and the debtor customer, which will become law for the parties making it. This principle forms a contractual relationship and lays down the rights and obligations of the parties as

3 Sutan Remy Sjahdeini, Kebebasan Berkontrak dan Perlindungan yang Seimbang Bagi Para Pihak Dalam Perjanjian Kredit Bank di Indonesia, xInstitut Bankir Indonesia, Jakarta, 1993, page.158 
mutually agreed upon. In banking practice, credit agreements are made in writing and in the form of standard agreements.

Previous research that has been conducted includes examining the position of standard agreements in relation to the principle of freedom of contract. ${ }^{4}$ The aspect of justice has not been discussed in this research. Research on the position of the standard agreement in relation to the principle of freedom of contract. ${ }^{5}$ This research only discusses the challenge of freedom of contract.

Regarding the implementation of Fintech, especially peer to peer landing (P2PL), the standard agreement is one of the clausulas in OJK Regulation No.77/POJK.01/2016 concerning Information Technology-Based Borrowing and Lending Services (POJK P2PL Services) with an emphasis on 2 (two) things that are prohibited from being listed, namely regarding the transfer of responsibility and submission of consumers to new provisions/changes in provisions. A more comprehensive arrangement regarding the standard agreement is regulated in the Financial Services Authority Circular Letter No. 13/SEOJK.07/2014 concerning the Standard Agreement (SEOJK Standard Agreement) which is the implementer of OJK Regulation No.1/POJK.07/2013 concerning Consumer Protection in the Financial Services Sector (POJK Consumer Protection).

The purpose of this study is to examine and analyze how fairness the credit agreement is in the presence of standard clausulas, which have always been disadvantaged by consumers.

\section{B. RESEARCH METHODS}

The method that researchers use is juridical empirical. Empirical juridical research is legal research regarding the enactment or implementation of normative legal provisions in action at any particular legal event that occurs in society. ${ }^{6}$ This research uses the concept of law where, law is positive norms in the national legal system of legislation, the research is doctrinal, namely law is a manifestation of the symbolic meanings of social behavior as seen in their interactions. Non-doctrinal legal research, the approach uses qualitative research. This research is based on the legal positivist concept which states that legal norms are identical to written norms and are made and promulgated by the competent state institutions. ${ }^{7}$

The types of data used in this research are primary data and secondary data, supported by primary legal materials, secondary legal materials, and tertiary legal materials. Primary data, namely data obtained directly from the main source in the form of views, thoughts, aspirations,

4 M.Roesli, Sarbini, Bastianto Nugroho, Kedudukan Perjanjian Baku Dalam Kaitannya Dengan Asas Kebebasan Berkontrak, Jurnal I/mu Hukum, Volume 15 Nomor 1 Februari 2019-Juli 2019, page.1-8

5 Yanti Malohing, Kedudukan Perjanjian Baku Kaitannya Dengan Asas Kebebasan Berkontrak, Lex Privatum, Vol.V/No.4/Jun/2017, page.5-17.

6 Abdulkadir Muhammad, Hukum dan Penelitian Hukum, Citra Aditya Bakti, Jakarta, 2004, page.134.

7 Ronny Hanitiyo Soemitro, Metodologi Penelitian Hukum, Ghalia Indonesia Jakarta, 1990, page.132. 
actions, events and legal relationships and words. ${ }^{8}$ This type of data provides information or information directly about everything related to the object of research, which is obtained directly through the field in the form of words and actions by means of in-depth interviews.

\section{RESULT AND DISCUSSION}

\section{The Fairness in Credit Agreements with Standard Clausula}

To understanding the law as a set of rules or positive norms in the legislation system that regulates human life with the help of supply chain management. Law is not only seen as rules, but also includes the operation of law in society. ${ }^{9}$ An agreement which is based on freedom of contract between parties who have a balanced relationship and strive to reach the agreement required for the agreement through a process of negotiation between the parties. However, nowadays many agreements in society occur not through a balanced negotiation process between the parties, but the agreement occurs in a way that one party has prepared standard terms on the agreement form that has been printed beforehand and then is put forward by the other party to be approved with almost no. gives the other party complete freedom to negotiate on the terms proposed. Such an agreement is called a standard agreement or standard agreement.

Standard agreements have long been used in various contracts, the use of standard agreements is closely related to advances in the economy that require efficiency in spending costs, time and energy. A standard agreeme nt is an agreement whose terms are standardized or determined by one party only, while the other party can only agree to it. Economically, the use of standard clausulas in standard agreements has practical advantages, reducing lengthy negotiations and cost savings, but legally it gives an unequal position to the parties because one party is usually forced to accept terms that have been standardized by the other.

Generally, the agreement has been made in a standard contract. Consumers can choose to agree or not. This condition causes a weak position of consumers as debtors when compared to consumer finance companies as creditors. To protect consumers from imbalance of their position in an agreement, a consumer protection law was formed, consumer protection law prohibits the inclusion of standard clausulas on any documents and/or agreements that conflict with applicable regulations. Thus, in every agreement it is necessary to see whether this provision is being complied with or not. ${ }^{10}$

8 Lexy J. Moleong, Metodologi Penelitian Kualitatif, Remaja Rosdakarya Offset, Bandung, 1998, page.112

9 Johny Khoesoema Hioe, Anis Mashdurohatun, Gunarto, Irwan Jasa Tarigan, Reconstruction of Pretrial Institution Function in Supervising Investigator Authorization Based on Justice Value with Moderating Role of Supply Chain Management, International Journal of Supply Chain Management, Vol. 9, No. 3, June 2020, page.613-619

10 Firya Oktaviarni, Penerapan Klausula Baku dalam Perjanjian Pembiayaan Konsumen Menurut Undang-Undang Nomor 8 Tahun 1999 tentang Perlindungan Konsumen, Jurnal IImu Hukum, Volume 6, Nomor 2, 2015, page.108 
The essence of justice is the fulfillment of everything that is a right and an obligation in the human relationship. This is based on the concept that underlies justice, namely the balance between rights and obligations. The principle of justice demands action that is proportional, appropriate, balanced, in line with the rights of everyone, while the principle of fairness emphasizes that banks pay attention to new values in society, be it related to morals and customs. In applying the principles of fairness and fairness, the credit agreement is prohibited from containing a clausula stating that the debtor customer is subject to new, additional, continuation and/or changes made unilaterally by the bank.

Realizing justice is a form of protection of human rights, both individuals and groups to lead to a safe, serene and prosperous society. This can be done by balancing the rights and obligations of the parties in an agreement, for example in a bank credit reciprocity agreement. The realization of the principle of justice in the contract made by the parties must be accompanied by the principle of balance. ${ }^{11}$ The agreement between the parties is essentially inseparable from the issue of justice, because in an agreement there must be a fair exchange of rights and obligations.

When designing, formulating, stipulating, a credit agreement in standard form, the bank is obliged to base the provisions concerning the prohibition of containing a clausula stating the transfer of responsibility, granting power of attorney from the customer to the bank, either directly or indirectly, to take all unilateral actions on goods pledged as collateral by the customer, unless the unilateral act is carried out based on laws and regulations; state that the customer is subject to new regulations, additions, continuation and/or changes made unilaterally by the bank during the period when the customer makes use of bank credit; states that the customer authorizes the bank to charge a mortgage, pledge or collateral right over the credit agreement to be utilized by the customer in installments.

The format of the credit agreement as a standard agreement stipulated in the Financial Services Authority Circular Letter concerning the Standard Agreement is that a credit agreement containing rights, obligations and requirements that bind the customer legally, must use letters, writing, symbols, diagrams, signs, terms, phrases can be read, and/or simple sentences in Indonesian that are easily understood by customers. The bank is obliged to provide an explanation that the customer has not understood, either in writing in the credit agreement, or orally before signing the credit agreement, if the customer finds uncertainty.

The credit agreement must contain a statement "this agreement has been adjusted to the provisions of laws and regulations including the regulations of the Financial Services Authority", meaning that each credit

11 Jonneri Bukit, Made Warka dan Krisnadi Nasution, Eksistensi Asas Keseimbangan Pada Kontrak Konsumen Di Indonesia, Jurnal IImu Hukum, Vol.14, No.28 Agustus 2018, page.28 
agreement made by the bank has been revised and updated and adjusted to the provisions issued by the Financial Services Authority by applying the principles balance, fairness and fairness.

Banks that violate the provisions of the Financial Services Authority are subject to administrative sanctions, among others in the form of: written warnings, fines, namely the obligation to restrict business activities, freeze business activities and revoke business permits, pay a certain amount of money, instead of a standard credit agreement, the bank as the creditor and the customer as the debtor is never balanced. The debtor has no power and must follow the provisions of the contents of the credit agreement that has been standardized by the bank. ${ }^{12}$ Consumers are not only faced with the problem of weak awareness and lack of understanding (education) of their rights as consumers. For example, these rights indicate that consumers do not have a balanced bargaining position. ${ }^{13}$ Meanwhile, the agreement law adheres to the principle of freedom of contract, in which this principle gives everyone the right to be able to enter into various agreements according to the wishes and conditions agreed upon by both parties, with subjective and objective conditions regarding the validity of an agreement are still fulfilled.

In principle, the making of standard agreements or contracts offering standard clausulas is not prohibited. This form of covenant is inevitable in modern life as it is today. Almost 99 percent of written agreements (contracts) are agreements with standard clausulas. This condition shows that business transactions that are taking place today are not going through a balanced negotiation process between the parties. One party has prepared standard terms in the form of an agreement form which is presented to the other party for agreement with almost no freedom for that party to negotiate.

The contents of this standard agreement are contrary to the provisions of Article 1338 paragraph (3) of the Civil Code, regarding each agreement must be carried out in good faith. ${ }^{14}$ Then it also contradicts the provisions of Article 1339 of the Civil Code which states that consent is not only binding on what is expressly determined in it, but also everything that according to its nature is demanded based on justice, custom or law. ${ }^{15}$

According to the researcher, the principle of freedom of contract as contained in Article 1338 paragraph (3) of the Civil Code, an agreement should be made in good faith, starting from pre-contractual, contractual and post-contractual, so that each party does not feel disadvantaged. Whereas Article 1339 of the Civil Code states that an

12 Sutan Remy Sjahdeini, Op Cit, page.2

13 Gunawan Widjaja dan Ahmad Yani, Hukum Tentang perlindungan Konsumen, Cet.Ketiga, Gramedia, Jakarta, 2003, page.3

14 Pasal 1338 ayat (3) KUHPerdata.

15 Pasal 1339 KUHPerdata 
agreement does not meet the requirements of good faith and propriety, appropriateness makes the agreement null and void.

Standard contracts, standard contracts or adhesion contracts are some of the terms used for agreements where all the clausulas have been standardized by the user and the other party basically has no opportunity to negotiate or request changes. ${ }^{16}$

Standard agreements generally have been printed (boilerplate) so that the other party does not have the opportunity to negotiate, the options are to take the contract or leave it. ${ }^{17}$ The same thing was said by Hondius. ${ }^{18}$ What has not been standardized is only related to a number of things, namely about the object being transacted and the amount of costs that must be borne. ${ }^{19}$

In the context of Islamic law, a standard contract is an agreement that binds the parties to be considered valid as long as there is no violation of other sharia provisions. Apart from this being a habit, this is also to create efficiency in conducting transactions. Islam does not prohibit custom as long as the custom does not violate the stipulated provisions.

Standard agreements in Islam may be used with due observance of several principles, namely: a). principle of agreement; b). the principle of equal rights and obligations. This principle is closely related to fairness in conducting transactions. As Murtadho Muthahari argues that justice can be seen from 3 meanings. 1). Justice means the balance or state of balance or not lame 2). Justice means equality, or eliminating discrimination. 3). justice means giving personal rights and giving rights to those who have the right. ${ }^{20} \mathrm{c}$ ). principle of responsibility. The principle of being responsible here is not only responsible to others. Responsibility in an Islamic economy is broader than that, namely being accountable to Allah SWT, who has given mandates to humans. Every transaction that we do must not conflict with the rules that have been established by Allah. This principle is born from the value of unity (oneness of Allah SWT); d). good faith principle; e). principles in accordance with sharia; f). principle of Khiyar. This principle is not only a reason for freedom of contract, but also broader than that. This principle implies that the standard agreement must first be submitted to the consumer who receives the standard contract.

Although the Banking Law stipulates that the provision of credit must be given based on a loan agreement or loan agreement, there are no further provisions regarding the form of the credit agreement. In

16 Sutan Remy Sjahdeini, Op.Cit. page.66

17 Munir Fuady, Hukum Kontrak (Dari Sudut Pandang Hukum Bisnis), Second Book, Citra Aditya Bakti, Jakarta, 2003, page.76

18 Salim Hs, Perancangan Kontrak dan Memorandum of Understanding (MoU), Sinar Grafika, Jakarta, 2007, page.70.

19 Sutan Remy Sjahdeini, Op.Cit, page.66

20 Eva Zulfa Nailufar, Pengupahan Berkeadilan Menurut Hukum Islam, Kajian UMP DKI, AEmpat, Jakarta, 2014, page.41. 
practice, credit agreements are often standard agreements. Banks usually have their own forms and here and there changes are made as necessary. However, all terms and conditions are standard. In this case, the debtor is only in a position to accept or not the credit agreement. If you accept all the terms and conditions in the credit agreement, the debtor must sign it. Conversely, if the debtor refuses, he does not need to sign the credit agreement. Article 1338 paragraph (1) of the Civil Code reflects the principle of freedom for the parties to be able to determine the contents of the agreement. However, there are still disagreements about whether the standard agreement meets the consensualism and freedom of contract principles or not. ${ }^{21}$ An agreement with a standard clausula is considered not fulfilling the principle of freedom of contract because it was made by one party, so the other party cannot express their will freely.

The birth of the consumer protection law is a response to the increasingly pinched position of consumers in developing businesses, the presence of this law is expected to be able to reduce business unfair and practices. ${ }^{22}$ The position at the bottom is used to suppress and take advantage of the economy. Consumer protection stands on 3 (three) general principles, namely (1) the principle of benefit, which includes the principle of security and consumer safety; (2) the principle of justice which includes the principle of balance; and (3) the principle of legal certainty. ${ }^{23}$

With the above principles, it is hoped that the birth of this consumer protection law will be able to prevent the emergence of business activities that lead to unfair business and practices that are rapidly developing in the midst of a free market. ${ }^{24}$

Article 7 of the consumer protection law also regulates the obligations of business actors, who in running their business must have good faith, serve consumers honestly and are not discriminatory. ${ }^{25}$ However, creditors still apply the contents of the standard agreement prohibited by the Civil Code and consumer protection laws. On the other hand, the provisions of Article 1337 of the Civil Code states that "a cause is prohibited if the cause is prohibited by law or if the cause is contrary to decency or with public order. ${ }^{26}$

Article 18 of Act No. 8 of 1999 concerning Consumer Protection, regulates the existence of standard clausulas, namely: stating the transfer of responsibilities of business actors; states that the business actor has the right to refuse the return of goods purchased by

21 H.ManS.Sastrawidjaja, Bunga Rampai Hukum Dagang, Alumni, Bandung, 2005, page.177.

22 Imam Sjahputra, Perlindungan Konsumen dalam Transaksi Elektronik, Alumni, Bandung, 2015, page.167.

23 Ahmadi Miru dan Sutarman Yodo, Hukum Perlindungan Konsumen, Raja Grafindo Persada, Jakarta, 2004, page.26.

24 Imam Sjahputra, Op.Cit, page.167.

25 Pasal 7 UUPK.

26 Pasal 1337 KUHPerdata. 
consumers; states that the business actor has the right to refuse the return of money paid for goods and/or services purchased by consumers; states that the power of attorney from consumers to business actors, either directly or indirectly, is to carry out all unilateral actions relating to goods purchased by consumers in installments; regulate the evidence regarding the loss of use of goods or use of services purchased by consumers; give business actors the right to reduce the benefits of services or reduce the assets of consumers which are the object of sale and purchase of services; declare the consumer's submission to regulations in the form of new, additional, advanced and/or further amendments made unilaterally by the business actor during the period when the consumer utilizes the service purchased; states that the consumer authorizes the business actor to impose a mortgage, lien or security right on goods purchased by consumers in installments.

Article 18 paragraph (2) states that "Business actors are prohibited from including standard clausulas whose location or shape is difficult to see or cannot read clearly, or whose disclosures are difficult to understand". Article 18 paragraph (3) states that "Every standard clausula that has been stipulated by a business actor in a document or agreement that meets the provisions as referred to in paragraph (1) and paragraph (2) shall be declared null and void by law". In its implementation, there are provisions in paragraph (3) that use standard clausulas which are located as regulated in paragraphs (1) and (2), which are still widely encountered. In paragraph (3) that "Business actors are obliged to adjust standard clausulas that are contrary to this law".

\section{Contract strategy in achieving Justice is contracted}

The Consumer Protection Act has provided guidelines for making standard contracts. It must be admitted that the consumer's position in a standard contract is limited to taking or rejecting the policy offered to him. On this basis, the state is also the party responsible for upholding consumer protection, so that every consumer can feel comfort and security.

A party with a weak position tends to only accept and sign the contents of the agreement because they do not have the bargaining power to change the contents of the contract. If based on the objectives to be achieved by the parties in an agreement, it can be seen that the agreement was made to get an agreement as well as a legal basis for the parties to do or not to do something.

One of the efforts that can be made to achieve fairness in the contract can be efforts to develop and supervise, the responsibility for guidance lies with the government as referred to in Article 29 of Act No. 8 of 1999, namely: the government is responsible for fostering the implementation of consumer protection that guarantees consumer rights and business actors and the implementation of consumer and business actor obligations; guidance by the government on the implementation of 
consumer protection as referred to in paragraph (1) shall be carried out by the Minister and/or the related technical ministers; the minister as intended in paragraph (2) coordinates the implementation of consumer protection;

(2) The fostering of the implementation of consumer protection as referred to in paragraph (2) includes efforts to: create a business climate and develop a healthy relationship between business actors and consumers; development of non-governmental consumer protection organizations; increasing the quality of human resources and increasing research and development activities in the field of consumer protection; Further provisions regarding the development of consumer protection are regulated by a Government Regulation.

Contract justice can be seen in an agreement when both parties reach an agreement to bind themselves together without any pressure from the other party, in this case the contract is carried out voluntarily.

Credit agreement at the bank, the position of the customer when they want to apply for credit, they must follow the rules that have been made by the bank, without any room for negotiation, it can be related to interest, payment methods or other provisions. In addition, this bargaining position is also related to the ability of the parties related to the economic situation they have.

Negotiation is an important thing in an agreement, by negotiating, both parties can find out the rights and obligations to be carried out. Negotiations in an agreement arise because the parties have their own goals that they want to aim at, so that with these negotiations it is hoped that an agreement can be reached.

The principle of negotiation itself is contained in the supply and demand (Aanbod En Aanvaarding), in the supply and demand the parties can exchange ideas and wishes for a specific purpose. Negotiations carried out in an agreement can also avoid one-sided contracts, this is contrary to the principle of proportionality and the principle of balance, in which both principles state that the existence of balance for the parties is an initial step in creating contracted justice.

Standard credit agreements in banking are a common thing. This makes it easier when signing a credit agreement. Consumers or customers as borrowers generally just need to sign without reading the details of the agreement. Problems will arise when the credit is experiencing problems and in the end there must be a dispute in court.

According to Mariam Darus Badrulzaman, the characteristics of the exonation clausula are: the contents are determined unilaterally by the seller (entrepreneur) whose position is relatively stronger than that of the buyer; the buyer (consumer) in no way determines the contents of the agreement; driven by his needs the buyer (consumer) is forced to 
accept the agreement; written form; prepared in advance in bulk or individually. ${ }^{27}$

In the contents of the standard agreement above, it is clear that the creditor forces his will to be approved and followed by the debtor as the consumer to override the provisions of Article 1266 of the Civil Code which aims to protect parties who are in a weak position (debtors) in the agreement and also limit the authority of strong parties (creditors). As for this Article 1266 of the Civil Code: The condition for invalidation is considered to be always included in a reciprocal agreement, if one of the parties does not fulfill its obligations. In such a case the agreement is not null and void, but the cancellation must be requested to the Court. This request must also be made, although the cancellation conditions regarding non-fulfillment of obligations are stated in the agreement. If the conditions for cancellation are not stated in the agreement, the Judge by observing the circumstances, at the request of the respondent, is free to give a period of time to fulfill the obligations, but that period cannot be more than one month.

The standard agreement in the bank credit agreement proves that the debtor in the Credit Agreement is the less fortunate party/is in a weak position, that is, with more obligations than their rights. In relation to the substance of the agreement between creditors and debtors in the banking credit agreement, it appears that the bank credit agreement in the form of a standard agreement does not or does not fulfill a sense of justice.

The meaning of this article is that the parties who enter into an agreement must comply with the provisions of this article, the parties may not cancel the agreement based on their own will for reasons of not fulfilling the obligations between one of the parties. The desire to cancel an agreement must be submitted to the Court. The wish to cancel must also be made even though the conditions for cancellation regarding nonfulfillment of the obligations are stated in the agreement. If the creditor continues to force his will to take the object of the agreement without a court order, the agreement ends immediately, the debtor is free from future responsibilities, and can claim back from the creditor for all that the debtor has paid in advance based on the agreement. ${ }^{28}$

The use of standard clausulas in an agreement arises from the needs that exist in the community itself, that in a business relationship that requires a deed that is quite complicated and costs a lot of money, with the standard clausula it is expected to cut the operational costs needed and shorten the time.

\section{CONCLUSION}

Fairness in the credit agreement with the existence of standard clausulas, namely that each party (creditors and debtors) must agree as

27 Sri Gambir Melati Hatta, Beli-Sewa Sebagai Perjanjian Tak Bernama: Pandangan Masyarakat dan Sikap Mahkamah Agung", Cetakan ke-3, Alumni, Bandung, 2000, page.149-151

28 Abdul Kadir Muhammad, Hukum Perjanjian, Alumni, Bandung, 2006, page.310. 
stated in the Credit Agreement, namely through the fair and free exchange of performance implementation, because an unbalanced agreement will greatly harm one of the parties and therefore will very touching the sense of justice in society. The standard agreement made by the bank, apart from not contradicting the law, must also uphold the sense of justice and balance of the parties. Negotiations carried out in an agreement can also avoid onesided contracts, and this is one of the first steps in creating a fair contract. Before signing the agreement, the parties should study in detail the clausulas contained in the agreement, or at least find out the legal basis used in the event of undesirable things.

\section{BIBLIOGRAPHY}

\section{Book:}

Abdul kadir Muhammad, 2004, Hukum dan Penelitian Hukum, Citra Aditya Bakti, Jakarta;

Abdul Kadir Muhammad, 2006, Hukum Perjanjian, Alumni, Bandung;

Ahmadi Miru dan Sutarman Yodo, 2004, Hukum Perlindungan Konsumen, Raja Grafindo Persada, Jakarta;

Eva Zulfa Nailufar, 2014, Pengupahan Berkeadilan Menurut Hukum Islam, Kajian UMP DKI, A-Empat, Jakarta;

Gatot Supramono, 2009, Perbankan dan Masalah Kredit, Rineka Cipta, Jakarta;

Gunawan Widjaja dan Ahmad Yani, 2003, Hukum Tentang perlindungan Konsumen, Cet.Ketiga, Gramedia, Jakarta;

H.ManS.Sastrawidjaja, 2005, Bunga Rampai Hukum Dagang, Alumni, Bandung;

Imam Sjahputra, 2015, Perlindungan Konsumen dalam Transaksi Elektronik, Alumni, Bandung;

Lexy J. Moleong, 1998, Metodologi Penelitian Kualitatif, Remaja Rosdakarya Offset, Bandung;

Munir Fuady, 2003, Hukum Kontrak (Dari Sudut Pandang Hukum Bisnis), Second Book, Citra Aditya Bakti, Jakarta;

Ronny Hanitiyo Soemitro, 1990, Metodologi Penelitian Hukum, Ghalia Indonesia Jakarta;

Salim Hs, 2007, Perancangan Kontrak dan Memorandum of Understanding (MoU), Sinar Grafika, Jakarta;

Sri Gambir Melati Hatta, 2000, Beli-Sewa Sebagai Perjanjian Tak Bernama: Pandangan Masyarakat dan Sikap Mahkamah Agund', Cetakan ke-3, Alumni, Bandung; 
Sutan Remy Sjahdeini, 1993, Kebebasan Berkontrak dan Perlindungan yang Seimbang Bagi Para Pihak Dalam Perjanjian Kredit Bank di Indonesia, xInstitut Bankir Indonesia, Jakarta;

\section{Journal:}

Firya Oktaviarni, Penerapan Klausula Baku dalam Perjanjian Pembiayaan Konsumen Menurut Undang-Undang Nomor 8 Tahun 1999 tentang Perlindungan Konsumen, Jurnal IImu Hukum, Volume 6, Nomor 2, 2015;

Johny Khoesoema Hioe, Anis Mashdurohatun, Gunarto, Irwan Jasa Tarigan, Reconstruction of Pretrial Institution Function in Supervising Investigator Authorization Based on Justice Value with Moderating Role of Supply Chain Management, International Journal of Supply Chain Management, Vol. 9, No. 3, June 2020;

Jonneri Bukit, Made Warka dan Krisnadi Nasution, Eksistensi Asas Keseimbangan Pada Kontrak Konsumen Di Indonesia, Jurnal IImu Hukum, Vol.14, No.28 Agustus 2018;

Lathifah Hanim, MS.Noorman, Penyelesaian Perjanjian Kredit Bank Sebagai Akibatforce Majeure Karena Gempa Di Yogyakarta, Jurnal Pembaharuan Hukum, Volume III No. 2 Mei - Agustus 2016;

M.Roesli, Sarbini, Bastianto Nugroho, Kedudukan Perjanjian Baku Dalam Kaitannya Dengan Asas Kebebasan Berkontrak, Jurnal IImu Hukum, Volume 15 Nomor 1 Februari 2019-Juli 2019;

Yanti Malohing, Kedudukan Perjanjian Baku Kaitannya Dengan Asas Kebebasan Berkontrak, Lex Privatum, Vol.V/No.4/Jun/2017. 